\title{
Buchariate: An Aromatic Ester from Salvia bucharica
}

\author{
V. U. Ahmad ${ }^{1}$, M. Zahid ${ }^{2}$, M. S. Ali ${ }^{1}$, S. Ahmad ${ }^{1}$, Z. Ali ${ }^{1}$, M. Z. Iqbal ${ }^{2}$ and \\ R.B.Tareen ${ }^{3}$ \\ ${ }^{1}$ H.E.J. Research Institute of Chemistry, University of Karachi, Karachi-75270, Pakistan \\ ${ }^{2}$ Institute of Chemistry, University of the Punjab, Lahore, Pakistan. \\ ${ }^{3}$ Department of Botany, Baluchistan University, Quetta, Pakistan.
}

Salvia bucharica belonging to the family Lamiaceae (Labiatae), afforded a new aromatic ester named buchariate [ 1- ( $p$-hydroxybenzoyloxy )-3-oxo-octane (1)] along with twelve known constituents for the first time from our investigated source. The structures of all the isolated constituents were determined through spectroscopic techniques and comparison with literature values. The structure of new constituent (1) was elucidated through extensive 2-D NMR experiments.

(Keywords: Salvia bucharica, Lamiaceae, Buchariate, Aromatic ester, Characterization, 2DNMR)

\section{Introduction}

Salvia is the largest genus of the family Lamiaceae, previously called Labiatae. ${ }^{1}$ Various members of the genus Salvia have immense medicinal importance. Some interesting biological activities have been reported for extractives of various species of the this genus. The diterpenoids of $S$. officinalis show antiviral activity. ${ }^{2}$ Many Salvia species have also shown cytostatic and antibacterial activities. ${ }^{3-4}$ S. bucharica locally called "sursuadah" is an aromatic plant found in Pakistan, Afghanistan and Centra. ${ }^{5}$ The plant is used traditionally for the treatment of liver disorders.

Salvadiones-A, B and salvadiol have recently been reported by us. ${ }^{6-7}$ In this last communication on S.bucharica, we wish to describe the isolation and characterization of a new constituent, buchariate [1-( $p$-hydroxybenzoyloxy)-3-oxo-octane (1)] along with twelve known constituents which have never been isolated so far from our investigated source. They include: anagadiol, ${ }^{8}$ lupeol, ${ }^{9}$ oleanolic acid, ${ }^{10}$ stigmasterol, ${ }^{11}$ stigmasterol glucoside, ${ }^{11} \quad \beta$-sitosterol, ${ }^{11} \quad \beta$-sitosterol $\quad$ glucoside, ${ }^{11} \quad$ apigenin, ${ }^{12} \quad$ 7-O- $\beta$-Dglucnpyranosylapigeni, ${ }^{13}$ 5-hydroxy-4', 7-dimethoxy flavone, ${ }^{14-15}$ salvagenin $^{16}$ and crisilinol. $^{16}$ 


\section{Results and Discussion}

Compound 1 was obtained as a yellowish oil from the ethyl acetate soluble part of the methanolic extract of S.bucharica. The UV spectrum of 1 showed intense absorption bands at $\lambda_{\max } 274$ and $258 \mathrm{~nm}$. The IR spectrum exhibited strong absorption bands at 3410,1735 and $1720 \mathrm{~cm}^{-1}$ due to hydroxyl, ester and ketonic functions, respectively. The EI MS showed the molecular ion peak at $m / z$ 264. The base peak of stable acylium ion (Fig. 1a) appeared at $m / z 121$. The molecular formula was determined through HR MS as $\mathrm{C}_{15} \mathrm{H}_{20} \mathrm{O}_{4}$ (calcd. $m / z$ 264.1361, observed $\mathrm{m} / z$ 264.1365) showing six degrees of unsaturation.

The ${ }^{1} \mathrm{H}-\mathrm{NMR}$ spectrum of $\mathbf{1}$ showed a pair of doublets each with two protons integration at $\delta 7.07$ and 6.75 with a coupling constant of $8.6 \mathrm{~Hz}$. It showed the presence

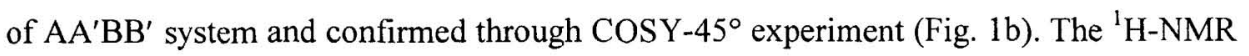
spectrum also showed three triplets each of two protons integration at $\delta 4.23(J=7.1 \mathrm{~Hz})$, $\delta 2.85(J=7.1 \mathrm{~Hz})$ and at $\delta 2.27(J=7.3 \mathrm{~Hz})$. The same coupling constants $(7.1 \mathrm{~Hz})$ of two triplets at $\delta 4.23$ and 2.85 indicated their adjacent positions and confirmed through $\operatorname{COSY}-45^{\circ}$ experiment. The remaining triplet at $\delta 2.27$ was due to the $\mathrm{H}-4$. Another most upfield triplet of three protons integration appeared at $\delta 0.87(J=7.2 \mathrm{~Hz})$ due to the only methyl present in the molecule. The triplets at $\delta 2.27$ and 0.87 were found to couple with a broad singlet of six protons integration at $\delta 1.24$ in $\operatorname{COSY}-45^{\circ}$ spectrum (Fig-1b), this broad singlet was due to the three carbon chain (H-5 - H-7).

The thirteen carbon signals in the BB spectrum were resolved through DEPT experiment into one methyl, six methylene, two methine and four quaternary carbon atoms. The downfield quaternary carbons at $\delta 211.4,167.1$ and 156.7 were assigned to $C$ 3, OCO and $\mathrm{C}-4$, respectively. All the chemical shifts $\left({ }^{1} \mathrm{H}\right.$ and $\left.{ }^{13} \mathrm{C}\right)$ were confirmed through HMQC, HMBC and COSY $-45^{\circ}$ techniques (Fig. 1b) and partial comparison with the reported data of related compounds. ${ }^{17}$

Thus, 1 is assigned as 1 - ( $p$-hydroxybenzoyloxy )-3-oxooctane and named buchariate. To the best of our knowledge this compound is not known yet from any natural source and therefore, would be a new addition in the constituents of S. bucharica as well as natural products. 


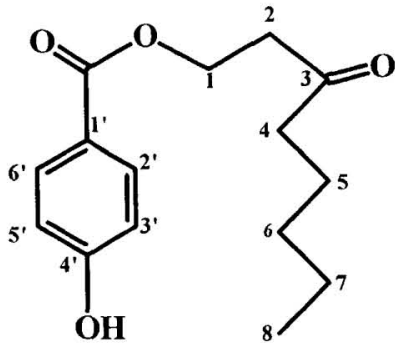

1

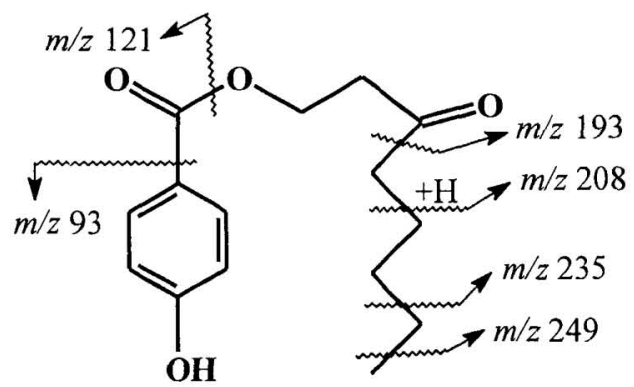

Fig. 2a Possible mass fragmentation of 2

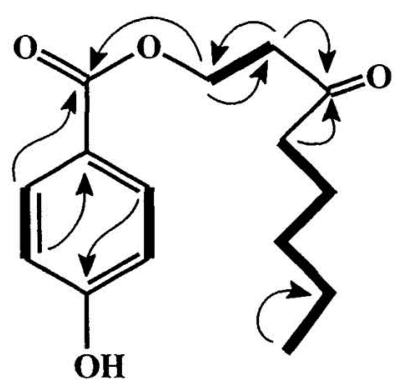

Fig. 2b H-H COSY $\mathrm{HMBC}$

\section{Experimental}

Optical rotation was measured on a JASCO DIP-360 polarimeter. The IR and UV spectra were recorded on JASCO 320-A and Hitachi UV 3200 spectrophotometers, respectively. The EI and HREI MS were recorded on $J M S H X 110$ with a data system and on JMS-DA 500 mass spectrometers. The ${ }^{1} \mathrm{H} \&{ }^{13} \mathrm{C}-\mathrm{NMR}, \mathrm{COSY}, \mathrm{HMQC}$ and $\mathrm{HMBC}$ spectra were taken in $\mathrm{CDCl}_{3}$ with TMS as an internal standard on Bruker AM-400 NMR spectrometer. 


\section{a) Collection and identification}

The plant material was collected from Baluchistan (Pakistan) in June, 1997, and identified by Dr. R. B. Tareen, Department of Botany, Baluchistan University, Quetta (Pakistan) where a voucher specimen (No. 354) of the plant material is deposited in the herbarium of the department.

\section{b) Extraction and isolation}

The air-dried $(6 \mathrm{Kg})$ and ground plant material was extracted with hexane $(15 \mathrm{~L} \mathrm{x}$ $3)$ and then with methanol $(15 \mathrm{~L} \times 2)$. After removing the methanol under reduced pressure, the methanolic gummy residue $(428.4 \mathrm{~g})$ was obtained. This was partitioned between EtOAc and $\mathrm{H}_{2} \mathrm{O}$. The EtOAc soluble part, after concentration (129.4g), was subjected to column chromatography over silica gel (70-230 mesh) using mixtures of hexane- $\mathrm{CHCl}_{3}$ and $\mathrm{CHCl}_{3}-\mathrm{MeOH}$ in order of increasing polarity as mobile phase.

The fractions eluted with $90 \% \mathrm{CHCl}_{3}$ in hexane were subjected to repeated flash chromatography ( $\mathrm{Si}$. gel 230-400 mesh) using various combinations of hexane-acetone. Repeated preparative TLC ( $\mathrm{Si}$ gel $\mathrm{F}_{254}$ ) of fraction obtained with $10 \%$ acetone in hexane from flash chromatography, developed with $0.5 \% \mathrm{MeOH}$ in $\mathrm{CHCl}_{3}$, afforded 1 as an oil (16.1 mg, $0.00026 \%$ ).

1- ( $\boldsymbol{p}$-hydroxybenzoyloxy )-3-oxooctane (1). $\mathrm{C}_{15} \mathrm{H}_{20} \mathrm{O}_{4} \cdot[\alpha]_{\mathbf{D}}{ }^{29} 0^{\circ}(c) 0.411$, $\left.\mathrm{CHCl}_{3}\right)$; IR $v_{\max }\left(\mathrm{CHCl}_{3}\right) \mathrm{cm}^{-1}: 3410(\mathrm{OH}), 1720(\mathrm{C}=\mathrm{O}), 1735(\mathrm{OCO})$; UV (MeOH), $\lambda_{\max }$ nm (log $\epsilon): 274$ (0.75), 258 (1.22); HREI MS: $m / z$ 264.1365; EI MS $m / z$ (rel. int.): 464 $[\mathrm{M}]^{+}(8), 121(100)$ and see Fig. 1a; ${ }^{1} \mathbf{H}-\mathbf{N M R}\left(\mathrm{CDCl}_{3}, 400 \mathrm{MHz}\right): \delta 7.07(2 \mathrm{H}, \mathrm{d}, J=8.6$ $\mathrm{Hz}, \mathrm{H}-2^{\prime}$ and H-6 $), 6.75\left(2 \mathrm{H}, \mathrm{d}, J=8.6 \mathrm{~Hz}, \mathrm{H}-3^{\prime}\right.$ and H-5 $\left.{ }^{\prime}\right), 4.23$ (t, $\left.J=7.1 \mathrm{~Hz}, \mathrm{H}-1\right), 2.85$ (t, $J=7.1 \mathrm{~Hz}, \mathrm{H}-2), 2.27$ (t, $J=7.3 \mathrm{~Hz}, \mathrm{H}-4$ ), 1.24 (6H, br.s, H-5 - H-7), 0.87 (t, $J=7.2$ $\mathrm{Hz}, \mathrm{H}-8) ;{ }^{13} \mathrm{C}-\mathrm{NMR}\left(\left(\mathrm{CDCl}_{3}, 125 \mathrm{MHz}\right): \delta 127.4\left(\mathrm{C}-1^{\circ}\right), 130.1\left(\mathrm{C}-2^{\prime}\right.\right.$ and C-6 $), 115.4$ (C-3' and C-5'), 156.7 (C-4'), 167.1 (OCO), 64.9 (C-1), 34.4 (C-2), 211.4 (C-3), 31.9 (C4), 29.3 (C-5), 29.2 (C-6), 25.0 (C-7) and 22.7 (C-8). 


\section{References}

1. Chadha Y. R. (1972), 327, The Wealth of India, Publication and Information Directorate

2. Tada M., Okuno K., Chiba K., Ohnishi E., Yoshi T. (1994), Phytochemistry 35: 539

3. Darias V., Bravo L., Rabanal R., Sanchez-Mateo C. C., Martin-Herrera D. A. (1990), Planta Medica 56: 70

4. Ahmad S., Kapadia Z., Badar Y. (1994), Fitoterapia LXV: 271

5. Ali S I., Nasir E. (1990), 192, 197, Flora of Pakistan, Eds BCC \& T Press, University of Karachi

6. Ahmad V.U., Zahid M., Ali M.S., Ali Z., Jassbi A.R., Clardy J., Lobkovsky E., Tareen R.B., Iqbal M.Z. (1999), J.Org.Chem. 64: 8465

7. Ahmad V. U., Zahid M., Ali M. S., Choudhary M. I., Akhtar F., Ali Z., Iqbal M. Z.(1999), Tetrehedron Lett. 40: 7561

8. Gonzalez A.G., Fraga B M., Gonzalez P., Hernandez M. G., Ravelo,A.G.(1981), Phytochemistry 20: 1919

9. McLean R.S., Poplawski J., Enriquez R.G., Escobar L.I., Leaon,I. (1986), Tetrahedron 706

10. Ahmad V.U., Atta-ur-Rahman. (1994), 2:67, 111, Handbook Natural Products Data

11. Sadikun A., Aminah I., Ismail N., Ibrahim P. (1996), Nat. Prod. Sci. 2(1): 19

12. Agrawal P. K., Schneider H. J. (1983), Tetrahedron Lett. 24: 144

13. Loo P.V., Bruyn A. D., Budesinksy M. (1986), Mag. Res.Chem. 24: 879

14. Redaelli C., Formentini L., Santaniello E. (1980), Phytochemistry 19: 985

15. Harbone J. B., Mabry T.J., Mabry H.(1976), pp. 45, 78, The Flavanoids, Academic Press, Newyork

16. Chari V.M., Grayer-Barkameijer R.J.,Harborne J.B., Osterdahl B.G.(1981), Phytochemistry 20: 1977

17. Scott K. N. (1972). J. Am. Chem., 94: 8564 